American Journal of Applied Sciences 5 (5): 540-547, 2008

ISSN 1546-9239

(C) 2008 Science Publications

\title{
Comparative Performance of Direct Injection Diesel Engines Fueled Using Compressed Natural Gas and Diesel Fuel Based on GT-POWER Simulation
}

\author{
${ }^{1}$ Semin, ${ }^{2}$ Abdul R. Ismail and ${ }^{2}$ Rosli A. Bakar \\ ${ }^{1}$ Institute of Technology Sepuluh Nopember Surabaya, Indonesia \\ ${ }^{2}$ Faculty of Mechanical Engineering, University Malaysia Pahang, Malaysia
}

\begin{abstract}
The paper is investigated the application of compressed natural gas (CNG) as an alternative fuel and its performance effect in the diesel engines using GT-POWER computational simulation. The $\mathrm{CNG}$ as an alternative fuel for four stroke diesel engine modeling was developed from the real diesel engine using GT-POWER computational model with measure all of engine components size. The computational model will be running on mono CNG fuel and mono diesel fuel to simulate and investigate the engine performance effect on the difference fuel. Output of the model simulation shown the effect of diesel engine fueled by CNG performance effect were simulated in any engine speeds parameters.
\end{abstract}

Keywords: Comparative performance, compressed natural gas, diesel engines, simulation

\section{INTRODUCTION}

In the diesel engines, the details of the diesel engine design vary significantly over the engine performance and size range. In particular, different combustion chamber geometries and fuel injection characteristics are required to deal effectively with major diesel engine design problem achieving sufficiently rapid fuel-air mixing rates to complete the fuel-burning process in the time available. A wide variety of inlet port geometries, cylinder head and piston shapes, and fuel-injection patterns are used to accomplish this over the diesel size range. Heywood ${ }^{[6]}$ written that the engine ratings usually indicate the highest power at which manufacturer expect their products to give satisfactory of power, economy, reliability and durability under service conditions. Maximum torque and the speed at which it is achieved, is usually given also.

The Compressed Natural Gas (CNG) has long been used in industries and stationary engines, but the application of $\mathrm{CNG}$ as a transport fuel has been considerably advanced over the last decade by the development of lightweight high-pressure storage cylinders, see $\operatorname{Kato}^{[1]}$ and Sera ${ }^{[9]}$. Most existing of natural gas for vehicles engines use in the petrol engines with modified by after-market retrofit conversions and retain bi-fuel capability, Bakar ${ }^{[2]}$ and Johansson ${ }^{[3]}$. Bi-fuelled vehicle conversions generally suffer from a power loss and can encounter driveability problems, due to the design and/or installation of the retrofit packages. Significant improvements in power and driveability can be realized with more sophisticated, vehicle-specific retrofit kits, or in factory-built bi-fuelled vehicles. Engine and vehicle manufacturers are increasingly involved in the development of original engine equipment, especially for heavy-duty diesel replacement applications, although many still regard the demand as too limited and dispersed to warrant large-scale manufacture. They can be derived from petrol engines or may be designed for the purpose. Until manufacturer original equipment $(\mathrm{OE})$ engines are more readily available, however, the practice of converting diesel engines to spark ignition will continue, which involves the replacement of diesel fuelling equipment by a gas carburetor and the addition of an ignition system and spark plugs.

This paper is to explore the application of dedicated or mono fuel compressed natural gas (CNG) as an alternative fuel for diesel engines and its performance effect in the diesel engines using simulation. Dedicated natural gas engines are optimized for the natural gas fuel only using simulation, see Dyntar $^{[4]}$.

GT-POWER is the leading engine simulation tool used by engine and vehicle makers and suppliers and is suitable for analysis of a wide range of engine issues ${ }^{[7]}$. GT-POWER is designed applicable to all type of

Corresponding Author: Semin, Marine Engineering Department, Institute of Technology Sepuluh Nopember Surabaya, ITS Campus, Sukolilo, Surabaya 60111, Indonesia, Tel: +6231-5994251-54, ext. 1102-1103, Fax: +6231-5994754 
internal combustion engines and provides the user with many components to model any advanced concept. GTPOWER is based on one-dimensional gas dynamics, representing the flow and heat transfer in the piping and in the other component of an engine system. GTPOWER is one model from GT-SUITE software applications, Gamma Technologies ${ }^{[7]}$. A four-stroke direct-injection diesel engine typical was measured manually and modeled using GT-POWER in this paper to investigate the engine performance.

The investigation in this research is the performance effect of diesel fuel substituted to compressed natural gas (CNG) fuel as an alternative fuel for the same diesel engine specification. Its known that the properties of diesel fuel is difference with the properties of compressed natural gas (CNG) or methane. The vapor of diesel and CNG properties from GT-POWER is shown in Table 1. The objects were investigated in this reseach are brake power, brake torque, brake specific fuel consumption, volumetric efficiency and pressure in cylinder.

Table 1: Vapor fuel properties of diesel and CNG

\begin{tabular}{lcc}
\hline Vapor Fuel Properties & Diesel & CNG \\
\hline Carbon Atoms per Molecule & 13.5 & 1 \\
Hydrogen Atoms per Molecule & 23.6 & 4 \\
Oxygen Atoms per Molecule & 0 & 1 \\
Nitrogen Atoms per Molecule & 0 & 0 \\
Lower Heating Value (J/kg) & $4.325 \mathrm{e}+007$ & $2.111 \mathrm{e}+007$ \\
Critical Temperature (K) & 569.4 & 513 \\
Critical Pressure (bar) & 24.6 & 79.5 \\
Min. Valid Temperature (K) & 200 & 100 \\
Max. Valid Temperature (K) & 1200 & 1200 \\
Min. Valid Pressure (bar) & 0.01 & 0.01 \\
Max. Valid Pressure (bar) & 2000 & 300 \\
\hline
\end{tabular}

Heywood $^{[6]}$ and Ganesan ${ }^{[16]}$ have written that the importance of the diesel engine performance parameters are geometrical properties, the term of efficiency and other related engine performance parameters. The engine efficiencies are indicated thermal efficiency, brake thermal efficiency, mechanical efficiency, volumetric efficiency and relative efficiency. The other related engine performance parameters are mean effective pressure, mean piston speed, specific power output, specific fuel consumption, intake valve mach index, fuel-air or air-fuel ratio and calorific value of the fuel.

Diesel engine performance: In the diesel engine geometries design of Heywood ${ }^{[6]}$, diesel engine compression ratio is maximum cylinder volume or the displaced volume or swept $\left(V_{d}\right)$ and clearance volume $\left(V_{c}\right)$ divided by minimum cylinder volume $\left(V_{c}\right)$. And the power delivered by the diesel engine and absorbed by the dynamometer is the product of torque and angular speed. In the engine efficiencies, every its efficiencies defined by Ganesan ${ }^{[16]}$. Indicated thermal efficiency $\left(\eta_{i t h}\right)$ is the ratio of energy $(E)$ in the indicated power ( $i p$ ) to the input fuel energy. Brake thermal efficiency $\left(\eta_{b t h}\right)$ is the ratio of energy in the brake power $(b p)$, Mechanical efficiency $\left(\eta_{m}\right)$ is defined as the ratio of brake power $(b p)$ or delivered power to the indicated power (ip) or power provided to the piston and it can also be defined as the ratio of the brake thermal efficiency to the indicated thermal efficiency. Relative efficiency or efficiency ratio $\left(\eta_{\text {rel }}\right)$ is the ratio of thermal efficiency of an actual cycle to that of the ideal cycle, the efficiency ratio is a very useful criteria which indicates the degree of development of the engine. Ganesan ${ }^{[16]}$ written that the one of the very important parameters which decides the performance of four-stroke engines is volumetric efficiency $\left(\eta_{v}\right)$, where four-stroke engines have distinct suction stroke and therefore the volumetric efficiency indicates the breathing ability of the engine. The volumetric efficiency is defined as the volume flow rate of air into the intake system divided by the rate at which the volume is displaced by the system. The normal range of volumetric efficiency at full throttle for SI engines is $80 \%$ to $85 \%$ and for CI engines is $85 \%$ to $90 \%$. The other related engine performance was defined by

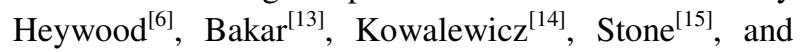
Ganesan $^{[16]}$.

Mean effective pressure (mep) where $n_{R}$ is the number of crank revolutions for each power stroke per cylinder (two for four-stroke, one for two-stroke cycles) as:

$$
\text { mep }=\frac{P n_{R}}{V_{d} N}
$$

The measure of an engine's efficiency which will be called the fuel conversion efficiency is given by Heywood $^{[6]}$ :

$$
n f=\frac{W_{c}}{m_{f} Q_{H V}}=\frac{\left(P n_{R} / N\right)}{\left(m_{f} n_{R} / N\right) Q_{H V}}=\frac{P}{m_{f} Q_{H V}}
$$

Specific fuel consumption as: 


$$
s f c=\frac{m_{f}}{P}
$$

In engine testing, both the air mass flow rate $m_{a}$ and the fuel mass flow rate $m_{f}$ are normally measured. The ratio of these flow rates is useful in defining engine operating conditions are air/fuel ratio (A/F) and fuel/air ratio (F/A).

The following relationships between diesel engine performance parameters can be developed.

For power $P$ :

$$
\begin{aligned}
& P=\frac{\eta_{f} m_{a} N Q_{H V}(F / A)}{n_{R}} \\
& P=\frac{\eta_{f} \eta_{v} N V_{d} Q_{H V} \rho_{a, i}(F / A)}{2}
\end{aligned}
$$

For torque T:

$$
T=\frac{\eta_{f} \eta_{v} V_{d} Q_{H V} \rho_{a, i}(F / A)}{4 \pi}
$$

For mean effective pressure:

mep $=\eta_{f} \eta_{v} Q_{H V} \rho_{a, i}(F / A)$

The specific power or the power per unit piston area is a measure of the engine designer's success in using the available piston area regardless of cylinder size. The specific power is:

$$
\frac{P}{A_{p}}=\frac{\eta_{f} \eta_{v} N L Q_{H V} \rho_{a, i}(F / A)}{2}
$$

Mean piston speed:

$$
\frac{P}{A_{p}}=\frac{\eta_{f} \eta_{v} N \overline{S_{p}} Q_{H V} \rho_{a, i}(F / A)}{4}
$$

Heywood[6] written that specific power is thus proportional to the product of mean effective pressure and mean piston speed. These relationship illustrate the direct importance to engine performance of high fuel conversion efficiency, high volumetric efficiency, increasing the output of a given displacement engine by increasing the inlet air density, maximum fuel/air ratio that can be useful burned in the engine and high mean piston speed.

Diesel engine thermodynamics: Ramadhas ${ }^{[10]}$ was analyzed the single zone thermodynamic model was used for analyzing the performance characteristics of four stroke direct injection diesel engines. The following fundamental assumptions have been made of cylinder charge is a homogeneous gas mixture of fuel vapor and air, pressure and temperature inside the cylinder are uniform and vary with crank angle, specific heats of the gaseous mixture are calculated as a function of temperature, as the combustion should always be of lean mixture, this leads to temperatures at which dissociation does not have much effect on thermodynamic performance of the engine. Thus the assumptions in dissociation with single zone model are generally acceptable for diesel engine simulations.

The energy balance equation for the Ramadhas ${ }^{[10]}$ can be written in differential form as:

$\frac{d(m u)}{d \theta}=\frac{d Q_{r}}{d \theta}-\frac{d Q_{h}}{d \theta}-\frac{d W}{d \theta}$

With a minor rearrangement and substitution for various terms, Eq. (10) can be written as :

$m \frac{d u}{d \theta}=\frac{d Q_{r}}{d \theta}-h A \frac{d T}{d \theta}-R T \frac{d V}{d \theta}$

Using engine kinematics the cylinder volume at any crank angle can be computed using the following equation:

$V(\theta)=V_{\text {dis }}\left[\frac{r}{r-1}-\frac{1-\cos \theta}{2}+\frac{1}{2} \sqrt{\left(2 \frac{L}{S}\right)^{2}-\sin ^{2} \theta}\right]$

The first derivative of Eq. (12) gives the rate of change of cylinder volume with respect to crank angle:

$$
\frac{d V}{d \theta}=\frac{V_{d i s p}}{2}\left[\frac{1}{2} \frac{\sin 2 \theta}{\sqrt{\left(2 \frac{L}{S}\right)^{2}-\sin ^{2} \theta}}-\sin \theta\right]
$$


The gas properties are functions of temperature and its composition has investigated by Riegler ${ }^{[5]}$, Ramadhas $^{[10]}$, Ghojel ${ }^{[11]}$ and Lapuerta ${ }^{[12]}$. The maximum temperature can be achieved for that system where the combustion is complete and the system is adiabatic and is known as adiabatic flame temperature. It depends on the chemical composition of the reactant mixture, pressure and temperature of the mixture and combustion process. A hydrocarbon fuel can be represented by $\mathrm{C}_{\mathrm{x}} \mathrm{H}_{\mathrm{y}} \mathrm{O}_{\mathrm{z}}$. The chemically correct amount of oxygen $\left(\mathrm{Y}_{\mathrm{cc}}\right)$ required for combustion per mole of fuel can be written as:

$Y_{\mathrm{CC}}=m_{\mathrm{C}}+0.25 m_{\mathrm{H}}-0.5 m_{\mathrm{O}}$

The minimum amount of oxygen required $\left(Y_{\min }\right)$ for combustion in the reactants per mole of fuel i.e. to convert $\mathrm{H}_{2}$ to $\mathrm{H}_{2} \mathrm{O}$ and $\mathrm{C}$ to $\mathrm{CO}$ can be expressed as:

$Y_{\min }=Y_{C C}-0.5 m_{C}$

Here $m_{\mathrm{C}}, m_{\mathrm{H}}$ and $m_{\mathrm{O}}$ are respectively the number of moles of carbon, hydrogen and oxygen atoms in one mole of fuel. Heat release due to combustion is calculated by using single Weibe's heat release correlation.

$$
\frac{d Q_{r}}{d \theta}=6.908 x(n+1) x\left(\frac{Q_{r}}{\theta_{t}}\right)^{n}\left(\frac{\theta}{\theta_{t}}\right)^{n} \exp \left[-6.908\left(\frac{\theta}{\theta_{t}}\right)^{n+1}\right]
$$

Ignition delay is the time period between the start of injection of fuel and beginning of its combustion. It is a complicated function of mixture temperature, pressure, equivalence ratio and the fuel properties.

$$
\int_{t_{i i j}}^{t_{i j n}} \frac{d t}{t(p, T)}=\frac{1}{K_{t_{i n j}}} \int_{t_{i i j}}^{t_{i j n}} \frac{d t}{(p(t))^{-q} \exp (E / R T(t))}=1
$$

The values of various constants appearing in Eq. (17) corresponding to direct injection diesel engines are $\mathrm{K}=$ $2272, \mathrm{q}=-1.19, \mathrm{E} / \mathrm{R}=4650$.

During the intake and compression processes heat flows from the cylinder wall to working fluid, whereas during all other processes heat flows from the working medium to wall, Ramadhas ${ }^{[10]}$. The amount of heat exchange between gases to wall as well as wall to gas is considerable and hence it directly affects the engine performance and its life. The method of computation of heat transfer coefficient due to convection is the key factor, which controls the order of magnitude of the rate of heat transfer. The convection heat transfer, $q_{c}$ in $\mathrm{kJ} /$ degree is given by:

$q c=h A(T g-T w) \Delta t$

The heat transfer coefficient, $\mathrm{h}$ in $\mathrm{W} / \mathrm{m}^{2} \mathrm{~K}$ is evaluated by using Hohenberg' equation given by:

$h=\frac{130 P^{0.8}\left(C_{m}+1.4\right)^{0.8}}{V_{C}^{0.06} T^{0.4}}$

Here $V_{C}$ is the cylinder volume $\left(\mathrm{m}^{3}\right), C_{m}$ is the mean piston speed $(\mathrm{m} / \mathrm{s})$.

\section{MATERIALS AND METHODS}

The single cylinder direct injection diesel engines have been modeled and simulated using diesel fuel and compressed natural gas fuel in this paper. The specification of the engine is presented in Table 2.

To simulate the engine performance in this paper, the research start on developed the GT-POWER of singlecylinder four-stroke direct-injection diesel engine modeling. The model is done step by step, the first step is open all of the selected diesel engine components to measure the engine components part size. Then, the engine components size data will be input to the GTPOWER library of the all engine components data. To create the GT-POWER model, select Window and then Tile with Template Library from the menu. This will place the GT-POWER template library on the left hand side of the screen.

Table 2: Diesel engine specification

\begin{tabular}{lc}
\hline Engine Parameters & Value \\
\hline Bore $(\mathrm{mm})$ & 86.0 \\
Stroke $(\mathrm{mm})$ & 70.0 \\
Displacement $(\mathrm{cc})$ & 407.0 \\
Number of cylinder & 1 \\
Connecting rod length $(\mathrm{mm})$ & 118.1 \\
Piston pin offset $(\mathrm{mm})$ & 1.00 \\
Intake valve open $\left({ }^{0} \mathrm{CA}\right)$ & 395 \\
Intake valve close $\left({ }^{0} \mathrm{CA}\right)$ & 530 \\
Exhaust valve open $\left({ }^{0} \mathrm{CA}\right)$ & 147 \\
Exhaust valve close $\left({ }^{0} \mathrm{CA}\right)$ & 282 \\
Maximum intake valve open $(\mathrm{mm})$ & 7.095 \\
Maximum exhaust valve open $(\mathrm{mm})$ & 7.095 \\
Valve lift periodicity $(\mathrm{deg})$ & 360 \\
\hline
\end{tabular}

The template library contains all of the available templates that can be used in GT-POWER. Some of these templates those that will be needed in the project 
need to be copied into the project before they can be used to create objects and parts. For the purpose of this model, click on the icons listed and drag them from the template library into the project library. Some of these are templates and some are objects that have already been defined and included in the GT-POWER template library, Gamma Technologies ${ }^{[7]}$. In this model the engine according to Bakar ${ }^{[8]}$ was breakdown to the tree system, there are intake system, engine cylinder and fuel injection system, and exhaust system. In the selected diesel engine, the intake system its have any component, size and different data. The system was started from environment till the intake valve. The engine cylinder and fuel injection system is focused in engine cylinder performance were support diesel fuel from fuel injection system, fresh air intake system and exhaust gas to exhaust system. There are any components in the engine cylinder and fuel injection system in the diesel engine. The components, size and data must be record and inserted to the GT-POWER form. The components are injector, cylinder and engine. The last system in the diesel engine is the exhaust system. In this system was started from exhaust valve and finished in the environment. All of this diesel engine components connected by orifficeconn. Then, the modeling the diesel engine model using GTPOWER software in this research can be developed. Data component and fuel nozzle hole needed for building an engine model. A list of information that is

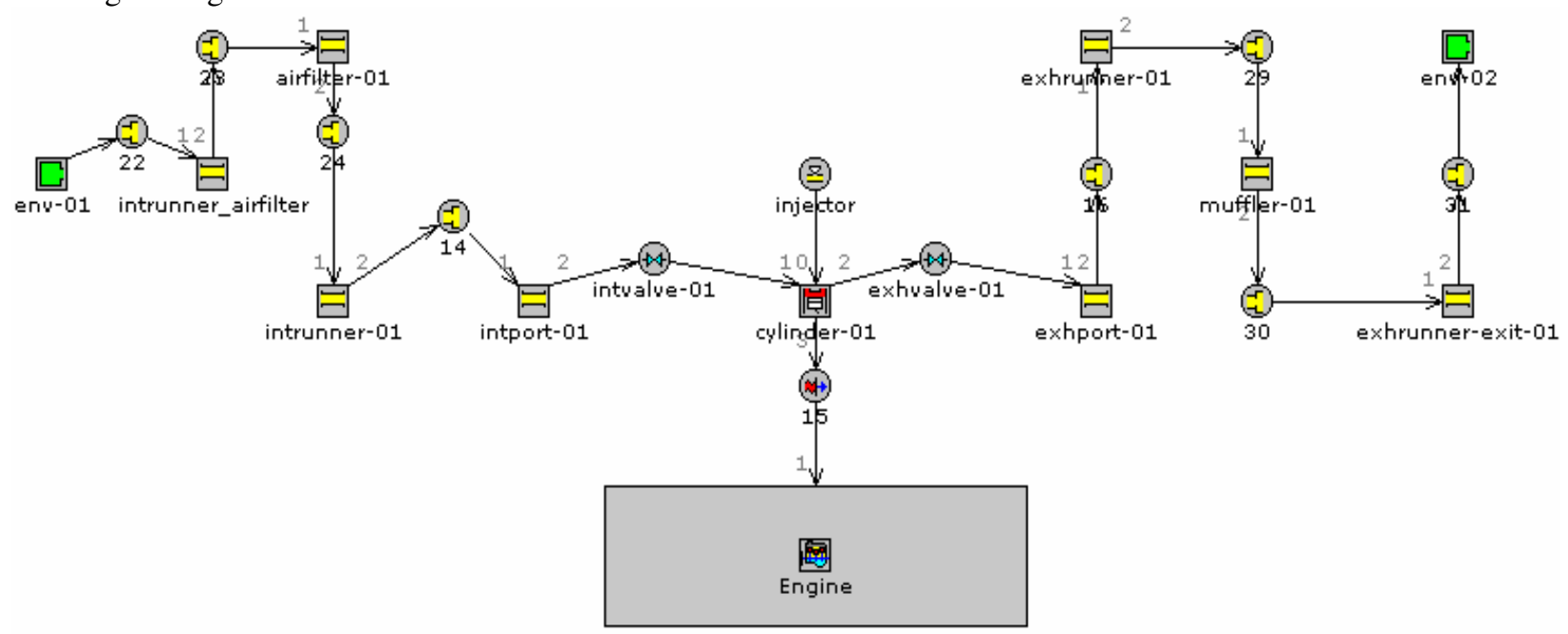

needed to build a model in GT-POWER is included in library. Not every item will be needed for all models. If the model is being built at an early design stage, determining optimal values for some of the items listed may be the purpose of the simulation. If this is the case, those particular attributes should be defined as parameters and run for a series of cases to determine an optimal value.

Data in engine characteristics are compression ratio, firing order, inline or $\mathrm{V}$ configuration, $\mathrm{V}$-angle (optional), 2 or 4 stroke. Data in cylinder geometry are bore, stroke, connecting rod length, pin offset, piston TDC clearance height, head bowl geometry, piston area and head area. Data in intake and exhaust system is geometry of all components. Data in throttles are throttle location and discharge coefficients versus throttle angle in both flow directions. Data in fuel injectors are location and number of injectors, number of nozzle holes and nozzle diameter, injection rate, fuel type and LHV. Data in intake and exhaust valves are valve diameter, lift profile, discharge coefficient, valve lash. Data in ambient state are pressure, temperature and humidity. Performance data can be very useful when tuning a model after it has been built. This research is focuses in diesel engine fuel changed to compressed natural gas simulation. The GT-POWER model development of single cylinder direct injection diesel engine is shown in Fig. 1.

Fig. 1: Single cylinder direct injection diesel engine model using GT-POWER 
In the GT-POWER model data entries, air with compositions of $76.7 \% \mathrm{~N}_{2}$ and $23.3 \% \mathrm{O}_{2}$ at pressure 1 bar and temperature $26.85^{\circ} \mathrm{C}$ is being input to env- 01 . The properties for env-02 are similar with env- 01 . The intake system consists of intrunner airfilter or intake runner for air filter, airfilter-01 and intrunner-01. These diesel engine parts represent the intake system pipes with specific parameters as shown in Table 3. The diesel engine exhaust system of GT-POWER model consists of exhport-01, exhrunner-01, muffler-01 and exhrunner-exit-01. These diesel engine parts also represent the exhaust system pipes with specific parameters as shown in Table 4. In the diesel engine model using GT-POWER, intvalve-01 represents intake valve and exhvalve-01 represents exhaust valve. The diesel engine component parameters of these valves are shown in Table 5.

Table 3: Engine parameters for intake system data

\begin{tabular}{lllll}
\hline & $\begin{array}{l}\text { Intrunne } \\
\text { airfilter }\end{array}$ & $\begin{array}{l}\text { Airfil } \\
\text { ter-01 }\end{array}$ & $\begin{array}{l}\text { Intrun } \\
\text { ner-01 }\end{array}$ & $\begin{array}{l}\text { Int } \\
\text { port-01 }\end{array}$ \\
\hline $\begin{array}{l}\text { Dia. inlet end } \\
(\mathrm{mm})\end{array}$ & 44.8800 & 159.63 & 40.44 & 40.69 \\
$\begin{array}{l}\text { Dia. outlet end } \\
(\mathrm{mm})\end{array}$ & 62.13 & 159.63 & 40.1 & 32.78 \\
$\begin{array}{l}\text { Length (mm) } \\
\text { Disc. length (mm) }\end{array}$ & 80 & 69.64 & 59.7 & 55.2 \\
$\begin{array}{l}\text { Wall temperat. } \\
\left({ }^{\circ} \mathrm{C}\right)\end{array}$ & 28.85 & 34.4 & 34.4 & 34.4 \\
\hline
\end{tabular}

Table 4: Engine parameters for exhaust system data

\begin{tabular}{lllll}
\hline & $\begin{array}{l}\text { exhport } \\
-01\end{array}$ & $\begin{array}{l}\text { exhrun } \\
\text { ner-01 }\end{array}$ & $\begin{array}{l}\text { Muffler } \\
-01\end{array}$ & $\begin{array}{l}\text { exhrun } \\
\text { ner- } \\
\text { exit-01 }\end{array}$ \\
\hline Dia. inlet end (mm) & 26.38 & 27.86 & 138.88 & 34.6 \\
Dia. outlet end (mm) & 29.82 & 27.86 & 138.88 & 34.6 \\
Length (mm) & 40.4 & 98 & 283.4 & 25.6 \\
Disc. length (mm) & 47.3 & 47.3 & 47.3 & 47.3 \\
Wall temperat. $\left({ }^{\circ} \mathrm{C}\right)$ & 480 & 480 & 480 & 480 \\
\hline
\end{tabular}

Table 5: Engine parameters for intake and exh. Valves

\begin{tabular}{lll}
\hline & Intvalve- & Exhvalve- \\
& 01 & 01 \\
\hline Valve diameter $(\mathrm{mm})$ & 35.54 & 29.04 \\
CAM timing angle $\left({ }^{\circ} \mathrm{CA}\right)$ & 462.5 & 214.6 \\
Valve lash $(\mathrm{mm})$ & 0.125 & 0.125 \\
\hline
\end{tabular}

\section{RESULTS AND DISCUSSION}

The GT-POWER simulation results for performance comparative of diesel engine fuelled using diesel fuel and CNG fuel are shown in Fig. 2, Fig. 3 and Fig. 4.

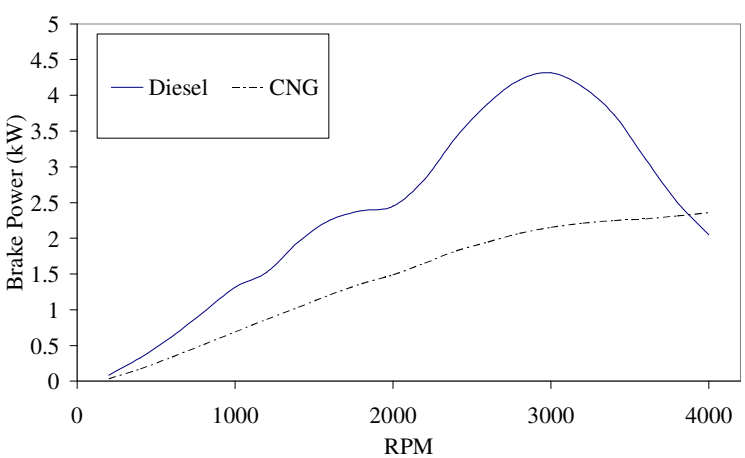

Fig. 2: Brake power performance of engine

Figure 2 shows that the diesel fuel is being used in the engine, the brake power changes from $0.09 \mathrm{~kW}$ at 200 $\mathrm{rpm}$ to $2 \mathrm{~kW}$ at $4000 \mathrm{rpm}$. The peak value is $4.3 \mathrm{~kW}$ at $3000 \mathrm{rpm}$ which is the maximum brake power for diesel fuel. Meanwhile when CNG fuel is being used the brake power changes from $0.04 \mathrm{~kW}$ at $200 \mathrm{rpm}$ to 2.4 $\mathrm{kW}$ at $4000 \mathrm{rpm}$. The maximum brake power for CNG fuel is $2.4 \mathrm{~kW}$ at $4000 \mathrm{rpm}$. By comparison, the maximum brake power of engine will reduce $44 \%$ when using $\mathrm{CNG}$ as fuel. The brake power performance effect of engine fuelled by diesel fuel and CNG fuel is shown in Fig. 2.

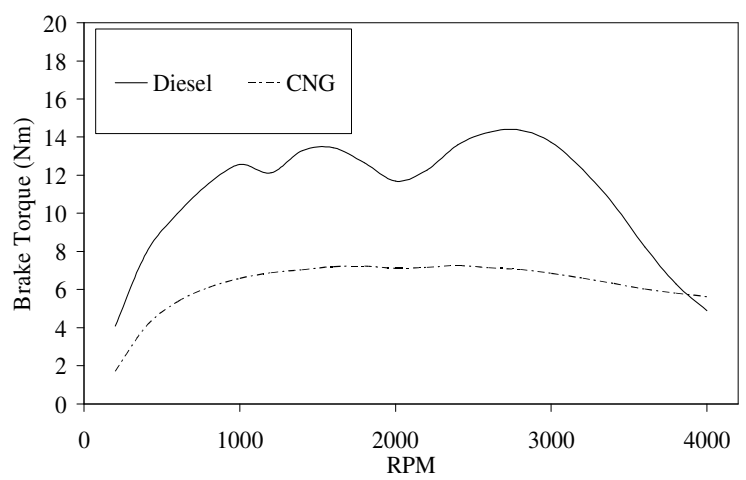

Fig. 3: Brake torque performance of engine

The brake torque versus rpm performance of engine fuelled by diesel fuel and CNG fuel is shown in Fig. 3. For diesel fuel, the brake torque changes from 4 $\mathrm{Nm}$ at $200 \mathrm{rpm}$ to $4.9 \mathrm{Nm}$ at $4000 \mathrm{rpm}$. There are three peak values; $12.6 \mathrm{Nm}$ at $1000 \mathrm{rpm}, 13.5 \mathrm{Nm}$ at 1500 $\mathrm{rpm}$ and $14.4 \mathrm{Nm}$ at $2700 \mathrm{rpm}$. The maximum brake torque is $14.4 \mathrm{Nm}$ at $2700 \mathrm{rpm}$. Meanwhile, for CNG fuel, the brake torque changes from $1.7 \mathrm{Nm}$ at $200 \mathrm{rpm}$ to $5.6 \mathrm{Nm}$ at $4000 \mathrm{rpm}$. The maximum brake torque for this fuel is $7.3 \mathrm{Nm}$ at $2400 \mathrm{rpm}$. By comparison, the maximum brake torque will reduce by $49 \%$ when using CNG as fuel. 


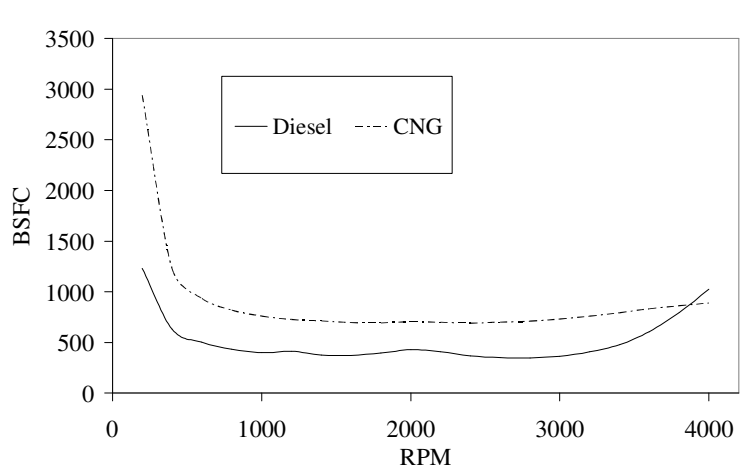

Fig. 4: Brake specific fuel consumption of engine

The brake specific fuel consumption of engine fuelled by diesel fuel and CNG fuel is shown in Fig. 4. For diesel fuel, the brake specific fuel consumption changes from $1232 \mathrm{~g} / \mathrm{kWh}$ at $200 \mathrm{rpm}$ to $1025 \mathrm{~g} / \mathrm{kWh}$ at $4000 \mathrm{rpm}$. The minimum brake specific fuel for diesel fuel is $349 \mathrm{~g} / \mathrm{kWh}$ at $2800 \mathrm{rpm}$. Meanwhile, for CNG fuel, the brake specific fuel consumption changes from $2940 \mathrm{~g} / \mathrm{kWh}$ at $200 \mathrm{rpm}$ to $891 \mathrm{~g} / \mathrm{kWh}$ at $4000 \mathrm{rpm}$.

The minimum value for this fuel is $691 \mathrm{~g} / \mathrm{kWh}$ at 2400 rpm. By comparison, the minimum brake specific fuel consumption will increase $49 \%$ when using CNG as fuel.

The usage of CNG in the small diesel engine will increase brake specific fuel consumption and reduction in terms of brake power and brake torque. This is because of gas $(\mathrm{CNG})$ fuel will reduce volumetric efficiency compared to liquid (diesel) fuel as shown in Fig. 5.

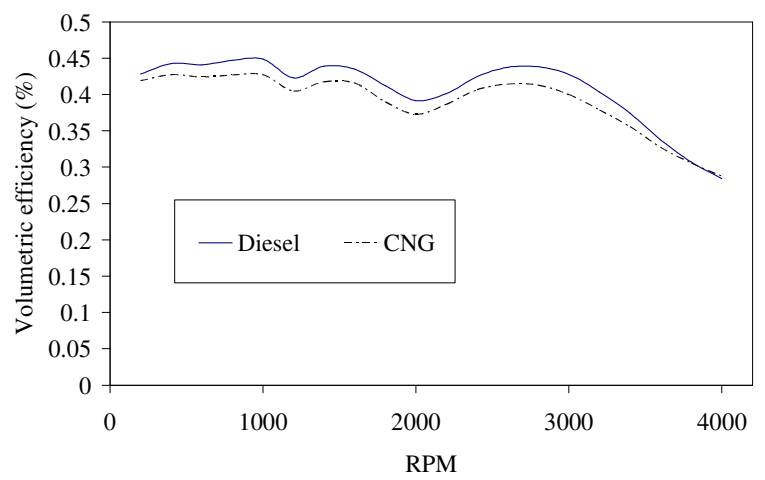

Fig. 5: Volumetric efficiency of engine

Another factor that must be considered is composition of hydrocarbon for each fuel. Diesel fuel which have higher hydrocarbon than CNG fuel, will give more energy to the engine as shown in Fig. 6, Fig. 7 through Fig. 8. At $1000 \mathrm{rpm}$ ignition process will occur at 5.7 and 4.5 degree crank angle for diesel and CNG respectively. The effect from this combustion will cause diesel fuel generates pressure 81 bar compare to $\mathrm{CNG}$ that will generates 70 bar. The pressure reduction is $8 \%$ from diesel fuel pressure. At $2000 \mathrm{rpm}$ ignition process will occur at 5.7 and 5.5 degree crank angle for diesel and CNG respectively. The pressures that will be generated are 76 bar and 67 bar for diesel fuel and CNG fuel respectively as shown in Fig. 7. The pressure reduction is $12 \%$ from diesel fuel pressure.

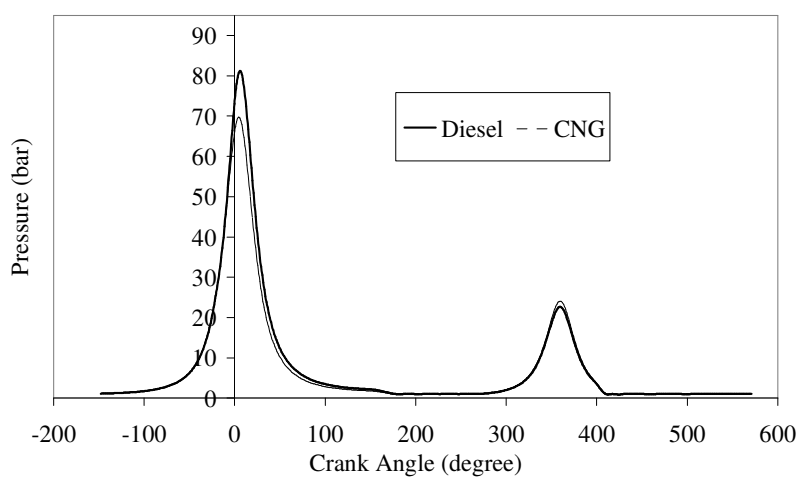

Fig. 6: Pressure engine with crank angle at $1000 \mathrm{rpm}$

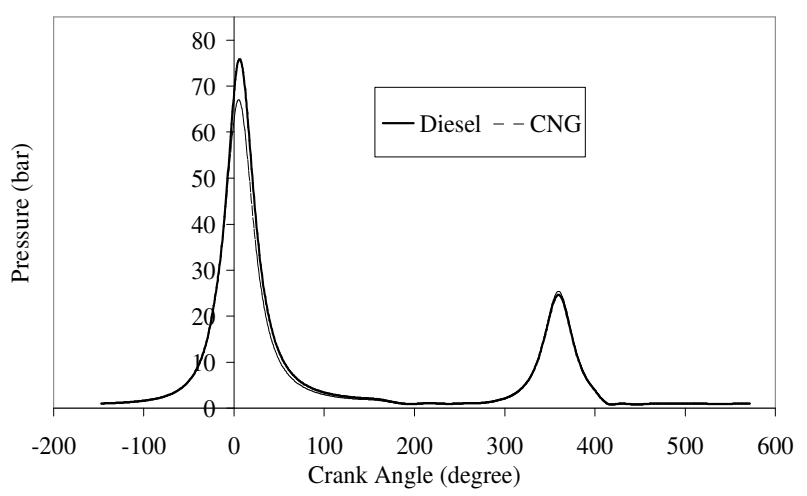

Fig. 7: Pressure engine with crank angle at $2000 \mathrm{rpm}$

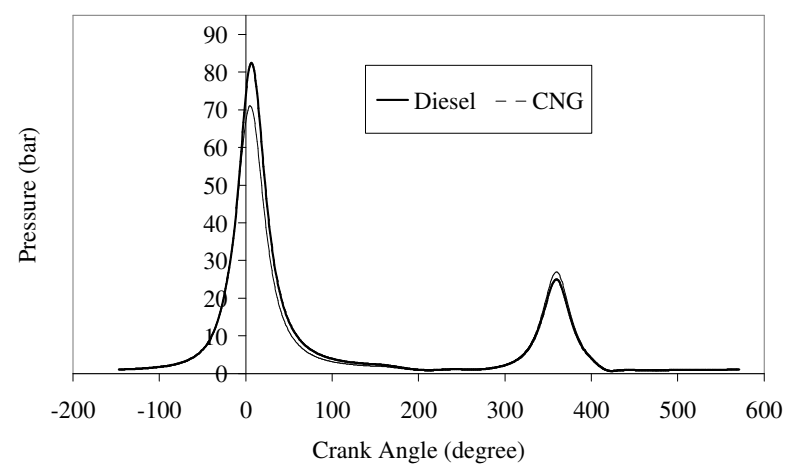

Fig. 8: Pressure engine with crank angle at $3000 \mathrm{rpm}$ 
Meanwhile at $3000 \mathrm{rpm}$, ignition process will occur at 6.2 and 5.1 degree crank angle for diesel fuel and CNG fuel respectively. The pressures that will be generated are 82 bar and 71 bar as shown in Fig. 8. The pressure reduction is $13 \%$ from diesel fuel pressure.

\section{CONCLUSION}

From these simulations of diesel engine fueled by compressed natural gas performance using GT-POWER simulation studies, it is observed that $\mathrm{CNG}$ can be used as an alternative fuel into diesel engine. The studied parameters show that there are reduction by $44 \%$ in brake power, $49 \%$ in brake torque and addition of $49 \%$ in brake specific fuel consumption. To ensure that the percentage can be reduced, the engine needs some modification. For further research, experimental study will be conducted to validate the simulation results and to reduce the percentages for the mentioned parameters.

\section{ACKNOWLEDGEMENTS}

We would like to acknowledge University Malaysia Pahang for providing the funding and facilities to support this research project and Institute of Technology Sepuluh Nopember Surabaya Indonesia for supporting the research project.

\section{REFERENCES}

1. Kato, T., Saeki, K., Nishide, H., Yamada, T., 2001. Development of CNG fueled engine with lean burn for small size commercial van, JSAE, Review 22, pp. 365-368.

2. Bakar, Rosli. A., Mardani,A.S., \& Wong, H.M., 2001. Heat Transfer Analysis in Cooling System of a CNG Fuelled SI Engine, BICET, Brunei.

3. Johansson, B., Olsson, K., 1995. Combustion Chambers for Natural Gas SI Engine Part 1: Fluid Flow and Combustion, SAE Transaction Paper 950469.

4. Dyntar, D.C., Onder, and Guzzella, L., 2002. Modelling and Control of CNG Engines, SAE Technical Paper Series, 2002-01-1295.

5. Riegler, U.G., Bargende, M. (2002). Direct Coupled 1D/3D-CFD-Computation (GTPower/Star-CD) of the Flow in the Switch-Over Intake System of an 8-Cylinder SI Engine with External Exhaust Gas Recirculation, SAE Technical Paper Series, 2002-01-0901.
6. Heywood, J.B., 1998. Internal Combustion Engine Fundamentals", McGraw-Hill, Singapore.

7. Gamma Technologies., 2004. GT-POWER User's Manual 6.1, Gamma Technologies Inc.

8. Bakar, Rosli.A., Semin., Ismail, Abdul.R., 2007. Effect Of Engine Performance For Four-Stroke Diesel Engine Using Simulation", Proceeding of The $5^{\text {th }}$ International Conference On Numerical Analysis in Engineering, Padang, Indonesia.

9. Sera, Mardani.A., Bakar, Rosli. A., Leong, Kwan. S., 2003. CNG Engine Performance Improvement Strategy through Advanced Intake System, SAE Technical Paper Series 2003-01-1937.

10. Ramadhas, A.S., Jayaraj, S., Muraleedharan, C., 2006. Theoretical modeling and experimental studies on biodiesel-fueled engine, Renewable Energy 31, 1813-1826.

11. Ghojel, Jamil., Honnery, Damon., Al-Khaleefi, Khaled., 2006. Performance, emissions and heat release characteristics of direct injection diesel engine operating on diesel oil emulsion, Applied Thermal Engineering 26, 2132-2141.

12. Lapuerta, Magı́n., Ballesteros, Rosario., Agudelo, John. R., 2006. Effect of the gas state equation on the thermodynamic diagnostic of diesel combustion, Applied Thermal Engineering 26, 1492-1499.

13. Bakar, Rosli.A., Semin., Ismail, Abdul.R., 2007. The internal combustion engine diversification technology and fuel research for the future: A Review, Proceeding of AEESEAP Regional Symposium on Engineering Education 2007, Kuala Lumpur Malaysia, Malaysia.

14. Kowalewicz, Andrzej., 1984. Combustion System of High-Speed Piston I.C. Engines, Wydawnictwa Komunikacji i Lacznosci, Warszawa.

15. Stone. Richard., 1997. Introduction to Internal Combustion Engines-Second Edition, SAE Inc., USA.

16. Ganesan, V., 1999. Internal Combustion Engines Second Edition, Tata McGraw-Hill, New Delhi. 